\title{
Mixed-Metal Rhenium-Platinum Cluster Compounds. Synthesis and Characterization of Three Isomers of the Triangular Cluster Complex $\left[\operatorname{Re}_{2} \operatorname{Pt}(\mu-\mathrm{H})_{2}(\mathrm{CO})_{8}\left(\mathrm{PPh}_{3}\right)_{2}\right]$
}

\author{
Tiziana Beringhelli, ' Alessandro Ceriotti, Giuseppe D'Alfonso, ${ }^{*}$ and Roberto Della Pergola \\ Centro CNR Sintesi Struttura Complessi Metalli di Transizione nei Bassi Stati di Ossidazione, Dipartimento di \\ Chimica Inorganica e Metallorganica, Via G. Venezian 21, 20133 Milano, Italy \\ Gianfranco Ciani," Massimo Moret, and Angelo Sironi
}

Istituto di Chimica Strutturistica Inorganica, Via G. Venezian 21, 20133 Milano, Italy

Received August 3, 1989

\begin{abstract}
The reaction between $\left[\mathrm{Re}_{2}(\mu-\mathrm{H})_{2}(\mathrm{CO})_{8}\right]$ and $\left[\mathrm{Pt}\left(\mathrm{PPh}_{3}\right)_{2}\left(\mathrm{C}_{2} \mathrm{H}_{4}\right)\right]$ at $273 \mathrm{~K}$ results in the insertion of the $\left[\mathrm{Pt}\left(\mathrm{PPh}_{3}\right)_{2}\right]$ fragment into a $\operatorname{Re}(\mu-\mathrm{H}) \operatorname{Re}$ bond, giving the triangular cluster $\left[\operatorname{Re}_{2} \mathrm{Pt}(\mu-\mathrm{H})_{2}(\mathrm{CO})_{8}\left(\mathrm{PPh}_{3}\right)_{2}\right]$, characterized spectroscopically. On increasing the temperature, an irreversible transformation occurs, due to the exchange of one phosphine and one carbonyl between platinum and rhenium. Two other isomers are formed in this way, characterized by ${ }^{1} \mathrm{H}$ and ${ }^{31} \mathrm{P} \mathrm{NMR}$, which differ in the location of the phosphine bound to rhenium. They equilibrate slowly on the NMR time scale, and variable-temperature experiments allowed the estimation of the thermodynamic parameters of this isomerization: $\Delta H^{\ominus}=-1.72 \pm 0.04 \mathrm{kcal}$ $\mathrm{mol}^{-1}, \Delta S^{\ominus}=-4.56 \pm 0.14 \mathrm{cal} \mathrm{mol}^{-1} \mathrm{~K}^{-1}$. NMR 2D reverse correlation experiments were performed to detect ${ }^{195} \mathrm{Pt}$ chemical shifts of the three isomers and to measure the passive couplings with ${ }^{31} \mathrm{P}$ not observable in the 1D spectra. The relative signs of these couplings are discussed. One of the isomers has been investigated by X-ray single-crystal analysis. It gives monoclinic crystals, space group $P 2_{1} / c$ (No. 14), with $a=14.044(3), b=19.343(5), c=16.391$ (3) $\AA, \beta=93.69(2)^{\circ}, Z=4$. The refinements, based on 5306 significant observations, gave a final $R$ value of 0.031 . It contains a $P t R e_{2}$ triangle with the $R e-R e$ edge and one of the $\mathrm{Pt}$-Re edges supposed to be bridged by hydride ligands. The $\mathrm{Pt}$ atom bears one $\mathrm{PPh}_{3}$ and one CO ligand and exhibits approximately a square-planar coordination. The two Re atoms show octahedral environments, one bearing four $\mathrm{CO}$ and the second one three $\mathrm{CO}$ and a $\mathrm{PPh}_{3}$ ligand, coordinated in the axial direction with respect to the cluster plane. The hydrogen-bridged Re-Re bond is 3.203 (1) $\AA$ long; the two Pt-Re bond lengths are 2.906 (1) and 2.788 (1) $\AA$, for the hydrogen-bridged edge and for the unbridged one, respectively.
\end{abstract}

\section{Introduction}

Mixed-metal cluster compounds are a field of high current interest, in view of the potential catalytic applications of polymetallic systems. As far as rhenium and platinum are concerned, heterogeneous catalysts obtained from compounds of these two metals have been extensively investigated in the past years. ${ }^{1}$ In contrast, less attention has been devoted to their chemical behavior in solution. ${ }^{2}$ We have, therefore, undertaken a systematic study of the reactivity between rhenium and platinum complexes, with the aim of obtaining compounds containing platinumrhenium bonds and studying their reactivity. The first synthetic method explored was the addition of a low-valent transition-metal complex across a metal-metal multiple bond. $^{3} \quad$ Stone and co-workers have demonstrated the ability of fragments isolobal with $\mathrm{CH}_{2}$, such as $\mathrm{PtL}_{2}$, to add ethylene-like molecules, giving inorganic analogues of cy-

(1) Augustine, S. M.; Sachtler, W. M. H. J. Catal. 1989, 116, 184, and references therein.

(2) (a) Howard, J. A. K.; Jeffery, J. C.; Laguna, M.; Navarro, R.; Stone, F. G. A. J. Chem. Soc. Dalton Trans. 1981, 751. (b) Jeffery, J. C.; Navarro, R.; Razay, H.; Stone, F. G. A. J. Chem. Soc., Dalton Trans. 1981, 2471. (c) Jeffery, J. C.; Razay, H.; Stone, F. G. A. J. Chem. Soc., Dalton Trans. 1982, 1733 . (d) Urbancic, M. A.; Wilson, S. R.; Shapley, J. R. Inorg. Chem. 1984, 23, 2954. (e) Powell, J.; Sawyer, J. F.; Stainer, M. V. R. J. Chem. Soc., Chem. Commun. 1985, 1314. (f) Jeffery, J. C.; Lewis, D. B.; Lewis, G. E.; Parrot, M. J.; Stone, F. G. A. J. Chem. Soc., Dalton Trans. 1986, 1717.' (g) Heidrich, J.; Loderer, D.; Beck, W. J. Organomet. Chem. 1986, 312, 329. (h) Al-Resayes, S. I.; Hitchcock, P. B.; Nixon, J. F. J. Chem. Soc., Chem. Commun. 1987, 928. (i) Casey, C. P.; Rutter E. W.; Haller, K. J. J. Am. Chem. Soc. 1987, 109,6886. (1) Henly, T. J.; Shapley, J. R.; Rheingold, A. L.; Geib, S. J. Organometallics 1988, 7, 441.

(3) Roberts D. A. Geoffroy, G. L. In Comprehensive Organometallic Chemistry; Wilkinson, G. Stone, F. G. A., Abel, E. W., Eds.; Pergamon Press: New York, 1982; Chapter 40 and references therein. clopropane. ${ }^{4}$ This suggested to us to react the formally unsaturated hydrido carbonyl complex $\left[\operatorname{Re}_{2}(\mu-\mathrm{H})_{2}(\mathrm{CO})_{8}\right]$ (1) ${ }^{5}$ with the lightly stabilized $\mathrm{PtL}_{2}$ fragment [Pt$\left.\left(\mathrm{PPh}_{3}\right)_{2}\left(\mathrm{C}_{2} \mathrm{H}_{4}\right)\right](2)$. We report here on the characterization of the three isomers of the triangular cluster complex $\left[\mathrm{Re}_{2} \mathrm{Pt}(\mu-\mathrm{H})_{2}(\mathrm{CO})_{8}\left(\mathrm{PPh}_{3}\right)_{2}\right]$ formed in this reaction. The treatment of compound 1 with the closely related complex $\left[\mathrm{Pt}\left(\mathrm{PPh}_{3}\right)\left(\mathrm{C}_{2} \mathrm{H}_{4}\right)_{2}\right]$ was reported ${ }^{6}$ to give a cluster of formula $\left[\mathrm{Re}_{2} \mathrm{PtH}_{2}\left(\mathrm{PPh}_{3}\right)(\mathrm{CO})_{9}\right]$, but unfortunately no details of this process are available.

\section{Results and Discussion}

The addition of 1 equiv of $\left[\mathrm{Pt}\left(\mathrm{PPh}_{3}\right)_{2}\left(\mathrm{C}_{2} \mathrm{H}_{4}\right)\right](2)$ to a dichloromethane solution of $\left[\operatorname{Re}_{2}(\mu-\mathrm{H})_{2}(\mathrm{CO})_{8}\right]$ (1) at room temperature allowed the isolation in high yield of a yellow complex (compound 3).

The mass spectra of this species were strongly misleading, because in the electron-impact spectrum the multiplet centered at $m / e 1318$ (corresponding to the expected product of replacement of ethylene by 1) was of negligible intensity (less than $1 \%$ ) and the fragments by far most intense were attributable to the recently characterized ${ }^{7}$ dinuclear rhenium complex $\left[\operatorname{Re}_{2}(\mu-\mathrm{H})(\mathrm{CO})_{8}(\mu-\right.$

(4) Barr, R. D.; Green, M.; Howard, J. A. K.; Marder, T. B.; Orpen, A. G.; Stone, F. G. A. J. Chem. Soc., Dalton Trans. 1984, 2757, and references therein.

(5) Bennet, M. J.; Graham, W. A. G.; Hoyano, J. K.; Hutcheon, W. L. J. Am. Chem. Soc. 1972, 94,6232.

(6) Quoted in ref 3 as: Stone, F. G. A., personal communication, 1978.

(7) Haupt, H. J.; Balsaa, P.; Florke, U. Inorg. Chem. 1988, 27, 280. 339 . 


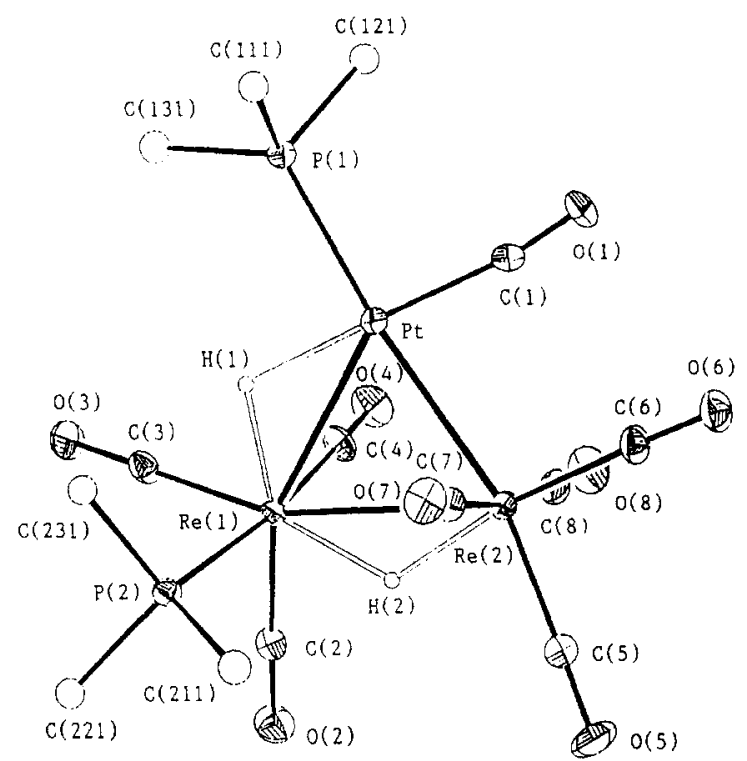

Figure 1. View of the solid-state structure of the complex $\left[\mathrm{Re}_{2} \mathrm{Pt}(\mu-\mathrm{H})_{2}(\mathrm{CO})_{8}\left(\mathrm{PPh}_{3}\right)_{2}\right]$.

$\left.\mathrm{PPh}_{2}\right)$ ]. With the fast atom bombardment (FAB) technique, the multiplet at $m / e 1318$ was more intense, but the most intense peaks were attributable to Stone's complex $^{6}\left[\mathrm{Re}_{2} \mathrm{PtH}_{2}(\mathrm{CO})_{9}\left(\mathrm{PPh}_{3}\right)\right]$. The formulation of 3 as the expected $\left[\mathrm{Re}_{2} \mathrm{Pt}(\mu-\mathrm{H})_{2}(\mathrm{CO})_{8}\left(\mathrm{PPh}_{3}\right)_{2}\right]$ complex was confirmed by a single-crystal $\mathrm{X}$-ray investigation, while multinuclear NMR analysis showed that in solution two isomers of 3 are present (see below).

Description of the Structure. The structure of compound 3 is shown in Figure 1. Bond distances and angles are given in Table I. It contains an irregular triangular $\mathrm{Re}_{2} \mathrm{Pt}$ cluster, with the platinum atom bearing one $\mathrm{CO}$ and one $\mathrm{PPh}_{3}$ ligand; one of the rhenium atoms bears three $\mathrm{CO}$ groups and the second $\mathrm{PPh}_{3}$ molecule, while the other rhenium atom binds four $\mathrm{CO}$ groups. The two hydride ligands, not directly located, are supposed, on the basis of the geometry of the other ligands and of the observed metal-metal bond-lengthening effects, to bridge the $R e-R e$ and the $\mathrm{Pt}-\mathrm{Re}(1)$ edges.

The rhenium-rhenium bond, 3.203 (1) $\AA$, is comparable to a number of similar interactions, elongated by a bridging hydride. ${ }^{8}$ The two $\mathrm{Pt}-\mathrm{Re}$ bond lengths are quite different, 2.788 (1) and 2.906 (1) $\AA$, the second value being associated with the hydride-bridged edge. The value of the shorter bond is smaller than that of the corresponding $\mathrm{Pt}-\mathrm{Re}$ unbridged interaction in the linear $\left[\operatorname{Re}_{2} \mathrm{Pt}(\mathrm{CO})_{12}\right]$ species, 2.8309 (5) $\AA$, ${ }^{2 \mathrm{~d}}$ probably due to decreased repulsions among ligands on different metals. It is also smaller than the value of the $\mathrm{Pt}-\mathrm{Re}$ interaction in $\left[\mathrm{Cp}(\mathrm{CO})_{2} \mathrm{HRePtH}-\right.$ $\left(\mathrm{PPh}_{3}\right)_{2}$ ], 2.838 (1) $\AA^{2 \mathrm{i}}$ On the other hand, the value of the longer bond is larger than that of the Pt-Re contact in the cation $\left[\mathrm{Cp}(\mathrm{NO}) \operatorname{Re}\left(\mu-\mathrm{PPh}_{2}\right)(\mu-\mathrm{H}) \mathrm{Pt}\left(\mathrm{PPh}_{3}\right)_{2}\right]^{+}, 2.8673$ (4) $\AA$, ${ }^{2 \mathrm{e}}$ which exhibits the simultaneous presence of a hydride and of a phosphide bridging ligand.

The coordination geometry around $\mathrm{Pt}$ could be considered distorted square planar, assuming as correct the position assigned to $H(1)$ and neglecting the $\mathrm{Pt}-\mathrm{Re}(1)$ interaction. The four bonds formed by platinum involve one phosphine, one carbonyl, one hydride, and the $\operatorname{Re}(2)$ atom. The observed angles at the metal atom are $\mathrm{P}(1)-$ $\mathrm{Pt}-\mathrm{Re}(2) 173.51$ (5), $\mathrm{P}(1)-\mathrm{Pt}-\mathrm{C}(1) 95.8$ (3), and $\mathrm{C}(1)-\mathrm{Pt}-$ $\operatorname{Re}(2) 78.1(3)^{\circ}$. The $\mathrm{Pt}-\mathrm{P}(1)$ and $\mathrm{Pt}-\mathrm{C}(1)$ bond lengths are normal, 2.322 (2) and 1.889 (10) $\AA$, respectively. The $\mathrm{CO}(1)$ group is almost linearly bound to $\mathrm{Pt}, \mathrm{Pt}-\mathrm{C}(1)-\mathrm{O}(1)$ $171.5(8)^{\circ}$, and the $\mathrm{C}(1) \cdots \operatorname{Re}(2)$ contact is too long $(>3 \AA)$
Table I. Selected Bond Distances $(\AA)$ and Angles (deg) within $\left[\operatorname{Re}_{2} \mathrm{Pt}(\mu-\mathrm{H})_{2}(\mathrm{CO})_{8}\left(\mathrm{PPh}_{3}\right)_{2}\right](3)$

\begin{tabular}{|c|c|c|c|}
\hline $\begin{array}{l}\mathrm{Pt}-\operatorname{Re}(1) \\
\mathrm{Pt}-\operatorname{Re}(2) \\
\operatorname{Re}(1)-\operatorname{Re}(2) \\
\mathrm{Pt}-\mathrm{P}(1) \\
\mathrm{Pt}-\mathrm{C}(1) \\
\operatorname{Re}(1)-\mathrm{P}(2) \\
\operatorname{Re}(1)-\mathrm{C}(2) \\
\operatorname{Re}(1)-\mathrm{C}(3) \\
\operatorname{Re}(1)-\mathrm{C}(4) \\
\operatorname{Re}(2)-\mathrm{C}(5) \\
\operatorname{Re}(2)-\mathrm{C}(6) \\
\operatorname{Re}(2)-\mathrm{C}(7) \\
\operatorname{Re}(2)-\mathrm{C}(8)\end{array}$ & $\begin{array}{l}2.906(1) \\
2.788(1) \\
3.203(1) \\
2.322(2) \\
1.889(10) \\
2.479(2) \\
1.913(8) \\
1.909(9) \\
1.942(9) \\
1.933(10) \\
1.918(9) \\
1.981(10) \\
1.971(11)\end{array}$ & $\begin{array}{l}C(1)-O(1) \\
C(2)-O(2) \\
C(3)-O(3) \\
C(4)-O(4) \\
C(5)-O(5) \\
C(6)-O(6) \\
C(7)-O(7) \\
C(8)-O(8) \\
P(1)-C(111) \\
P(1)-C(121) \\
P(1)-C(131) \\
P(2)-C(211) \\
P(2)-C(221) \\
P(2)-C(231)\end{array}$ & $\begin{array}{l}1.113(10) \\
1.157(9) \\
1.148(10) \\
1.142(10) \\
1.132(10) \\
1.160(10) \\
1.145(11) \\
1.147(11) \\
1.827(8) \\
1.833(8) \\
1.820(9) \\
1.827(9) \\
1.836(8) \\
1.838(8)\end{array}$ \\
\hline$P_{t}-R_{e}-t_{-1}$ & & $\mathrm{Pt}-\operatorname{Re}(2)-\mathrm{C}(8)$ & 91.7 \\
\hline $\operatorname{Re}(1)-\mathrm{Pt}-\mathrm{P}(1)$ & $118.06(5)$ & $\operatorname{Re}(1)-\operatorname{Re}(2)-C(5)$ & $109.1(3)$ \\
\hline $\operatorname{Re}(1)-\mathrm{Pt}-\mathrm{C}(1)$ & $140.8(3)$ & $\operatorname{Re}(1)-\operatorname{Re}(2)-\mathrm{C}(6)$ & $158.9(3)$ \\
\hline $\operatorname{Re}(2)-\mathrm{Pt}-\mathrm{P}(1)$ & $173.51(5)$ & $\operatorname{Re}(1)-\operatorname{Re}(2)-\mathrm{C}(7)$ & $92.8(3)$ \\
\hline $\operatorname{Re}(2)-\mathrm{Pt}-\mathrm{C}(1)$ & $78.1(3)$ & $\operatorname{Re}(2)-C(8)$ & $87.3(3)$ \\
\hline$-P t-C(1)$ & $95.8(3)$ & $\mathrm{C}(5)-$ & $91.6(4)$ \\
\hline $\operatorname{Pt}-\operatorname{Re}(1)-\operatorname{Re}(2)$ & 54.04 (1) & $\mathrm{C}(5)-\operatorname{Re}(2)-\mathrm{C}(7)$ & $93.0(4)$ \\
\hline $\mathrm{Pt}-\operatorname{Re}(1)-\mathrm{P}(2)$ & $106.95(5)$ & $C(5)-\operatorname{Re}(2)-C(8)$ & $93.7(4)$ \\
\hline $\mathrm{Pt}-\operatorname{Re}(1)-\mathrm{C}(2)$ & $154.2(3)$ & $C(6)-\operatorname{Re}(2)-C(7)$ & $89.7(4)$ \\
\hline$t-\operatorname{Re}(1)-C(3)$ & $106.5(3)$ & $e(2)-C(8)$ & $87.7(4)$ \\
\hline$t-\operatorname{Re}(1)-C(4)$ & $73.2(2)$ & $e(2)-C(8)$ & $172.9(4)$ \\
\hline $\operatorname{Re}(2)-\operatorname{Re}(1)-\mathrm{P}(2)$ & $101.92(5)$ & $\mathrm{Pt}-\mathrm{C}(1)-\mathrm{O}(1)$ & $171.5(8)$ \\
\hline $\operatorname{Re}(2)-\operatorname{Re}(1)-C(2)$ & $105.2(3)$ & $\operatorname{Re}(1)-\mathrm{C}(2)-\mathrm{O}(2)$ & $177.3(8)$ \\
\hline $\operatorname{Re}(2)-\operatorname{Re}(1)-C(3)$ & $160.3(3)$ & $\operatorname{Re}(1)-\mathrm{C}(3)-\mathrm{O}(3)$ & $179.5(8)$ \\
\hline $\operatorname{Re}(2)-\operatorname{Re}(1)-C(4)$ & 3) & (4) & $75.5(8)$ \\
\hline$P(2)-\operatorname{Re}(1)-C(2)$ & (2) & $\operatorname{Re}(2)-C(5)-C(5)$ & $179.2(9)$ \\
\hline $\mathrm{P}(2)-\operatorname{Re}(1)-\mathrm{C}(3)$ & $86.0(3)$ & $\operatorname{Re}(2)-C(6)-O(6)$ & $177.4(8)$ \\
\hline $\mathrm{P}(2)-\operatorname{Re}(1)-\mathrm{C}(4)$ & $172.7(3)$ & $\operatorname{Re}(2)-C(7)-O(7)$ & $175.4(8)$ \\
\hline$C(2)-\operatorname{Re}(1)-C(3)$ & $92.5(4)$ & $\operatorname{Re}(2)-\mathrm{C}(8)-\mathrm{O}(8)$ & $174.3(8)$ \\
\hline & $90.9(3)$ & $\mathrm{Pt}-\mathrm{P}(1)-\mathrm{C}(111)$ & $113.7(3)$ \\
\hline$-\mathrm{C}(4)$ & & $(121)$ & $.1(3)$ \\
\hline $\operatorname{Pt}-\operatorname{Re}(2)-\operatorname{Re}(1)$ & $57.54(1)$ & $\mathrm{Pt}-\mathrm{P}(1)-\mathrm{C}(131)$ & $121.0(3)$ \\
\hline $\mathrm{Pt}-\operatorname{Re}(2)-\mathrm{C}(5)$ & $165.3(3)$ & $\operatorname{Re}(1)-\mathrm{P}(2)-\mathrm{C}(211)$ & $119.2(3)$ \\
\hline $\mathrm{Pt}-\operatorname{Re}(2)-\mathrm{C}(6)$ & $102.2(3)$ & $\operatorname{Re}(1)-\mathrm{P}(2)-\mathrm{C}(221)$ & $115.4(3)$ \\
\hline $\mathrm{Pt}-\operatorname{Re}(2)-\mathrm{C}(7)$ & $82.3(3)$ & $\operatorname{Re}(1)-\mathrm{P}(2)-\mathrm{C}(231)$ & $112.8(3)$ \\
\hline
\end{tabular}

to imply any significant interaction.

The rhenium atoms display distorted octahedral coordination geometries. The $\operatorname{Re}(1)$ atom bears a $\mathrm{PPh}_{3}$ ligand in the axial direction with respect to the plane of the metal atoms, with a normal Re-P distance of 2.479 (2) $\AA$. The $\mathrm{CO}$ ligands bound to the rhenium atoms can be classified as follows: four carbonyl groups, two for each metal atoms, are equatorial (mean $\mathrm{Re}-\mathrm{C}$ and $\mathrm{C}-\mathrm{O}$ bond lengths 1.918 and $1.149 \AA$ ), one is axial trans to the phosphine [Re-C(4) and $\mathrm{C}(4)-\mathrm{O}(4) 1.942(9)$ and $1.142(10) \AA]$, and two are axial mutually trans (mean Re-C and C-O 1.976 and $1.146 \AA$ ).

The mean values of the bond angles at the $P$ atoms of the two triphenylphosphine ligands show some differences: $\mathrm{Pt}-\mathrm{P}(1)-\mathrm{C} 114.3, \mathrm{C}-\mathrm{P}(1)-\mathrm{C} 104.1$, vs $\operatorname{Re}(1)-\mathrm{P}(2)-\mathrm{C} 115.8$, $\mathrm{C}-\mathrm{P}(2)-\mathrm{C} 102.5^{\circ}$. The $\mathrm{P}(1)-\mathrm{C}$ bond lengths are on average shorter than the $\mathrm{P}(2)-\mathrm{C}$ ones (1.827 vs $1.834 \AA$ ).

The presence of the platinum atom in square-planar coordination makes the cluster two electrons shorter than what is required by the effective atomic number rule ( 46 valence electrons instead of 48).

NMR Characterization of the Isomers $3 a$ and $\mathbf{3 b}$. The ${ }^{1} \mathrm{H}$ and ${ }^{31} \mathrm{P}$ NMR spectra (Figure 2) of samples of compound 3 (either isolated by chromatography or purified by crystallization by the slow-diffusion technique) always showed the presence in solution of two species, whose ratio varied reversibly with the temperature. We assume therefore that in solution two isomers of compound $\mathbf{3}$ (3a and $3 \mathbf{b})$ are present, which at room temperature are equilibrating quickly from the chemical point of view but slowly on the NMR time scale.

The NMR data (Table II) of the isomer $3 a$, which is the major one at room temperature, are in agreement with the 
Table II. NMR Data for the Three Isomers of the Title Compound (Spectra Recorded in $\mathrm{CD}_{2} \mathrm{Cl}_{2}$ Solution at $273 \mathrm{~K}$ for $3 \mathrm{a}$ and $3 \mathrm{~b}$ and at $200 \mathrm{~K}$ for $3 \mathrm{c}$ )

\begin{tabular}{|c|c|c|c|c|c|c|c|c|c|c|c|c|}
\hline \multirow[b]{2}{*}{ compd } & \multicolumn{5}{|c|}{ chem shift, ${ }^{a} \mathrm{ppm}$} & \multicolumn{7}{|c|}{ coupling const, ${ }^{b} \mathrm{~Hz}$} \\
\hline & $\mathrm{H}_{\mathrm{a}}$ & $\mathrm{H}_{\mathrm{b}}$ & $\mathrm{P}_{\mathrm{a}}$ & $P_{b}$ & $\mathrm{Pt}^{c}$ & $\overline{\mathrm{H}_{\mathrm{a}}-\mathrm{P}^{d}}$ & $\mathrm{H}_{\mathrm{b}}-\mathrm{P}^{d}$ & $\mathrm{H}_{\mathrm{a}}-\mathrm{Pt}$ & $\mathrm{H}_{\mathrm{b}}-\mathrm{Pt}$ & $\mathrm{P}_{\mathrm{a}}-\mathrm{Pt}$ & $\mathrm{P}_{\mathrm{b}}-\mathrm{Pt}$ & $\overline{P_{a}-P_{b}}$ \\
\hline $3 \mathbf{a}$ & -6.71 & -14.31 & 44.4 & 14.5 & -4251 & $\begin{array}{l}14.2 \\
11.8\end{array}$ & $\begin{array}{c}3.0^{c} \\
13.2\end{array}$ & 668 & 35 & 2625 & $43^{c}$ & \\
\hline $3 \mathbf{b}$ & -7.42 & -14.82 & 41.9 & 15.0 & -4337 & $\begin{array}{r}18.8 \\
3.5\end{array}$ & $-\overline{18.6}$ & 534 & 32 & 2517 & $130^{c}$ & \\
\hline $3 \mathbf{c}$ & -9.22 & -15.62 & 25.3 & 15.2 & -4759 & $\begin{array}{l}12.8 \\
82.3\end{array}$ & & 502 & & 2167 & 4142 & 16.5 \\
\hline
\end{tabular}

${ }^{a}$ Downfield positive with respect to external $\mathrm{H}_{3} \mathrm{PO}_{4}$ for ${ }^{31} \mathrm{P}$ and with respect to $\mathrm{Na}_{2} \mathrm{PtCl}_{6}$ for ${ }^{195} \mathrm{Pt}$. ${ }^{b} \mathrm{Absolute}$ values. ${ }^{c} \mathrm{Determined}$ by ${ }^{1} \mathrm{H}-{ }^{195} \mathrm{Pt} 2 \mathrm{D}$ reverse-correlation experiments. ${ }^{d}$ The coupling in the first line refers to $\mathrm{P}_{\mathrm{a}}$, and that in the second one to $\mathrm{P}_{\mathrm{b}}$.
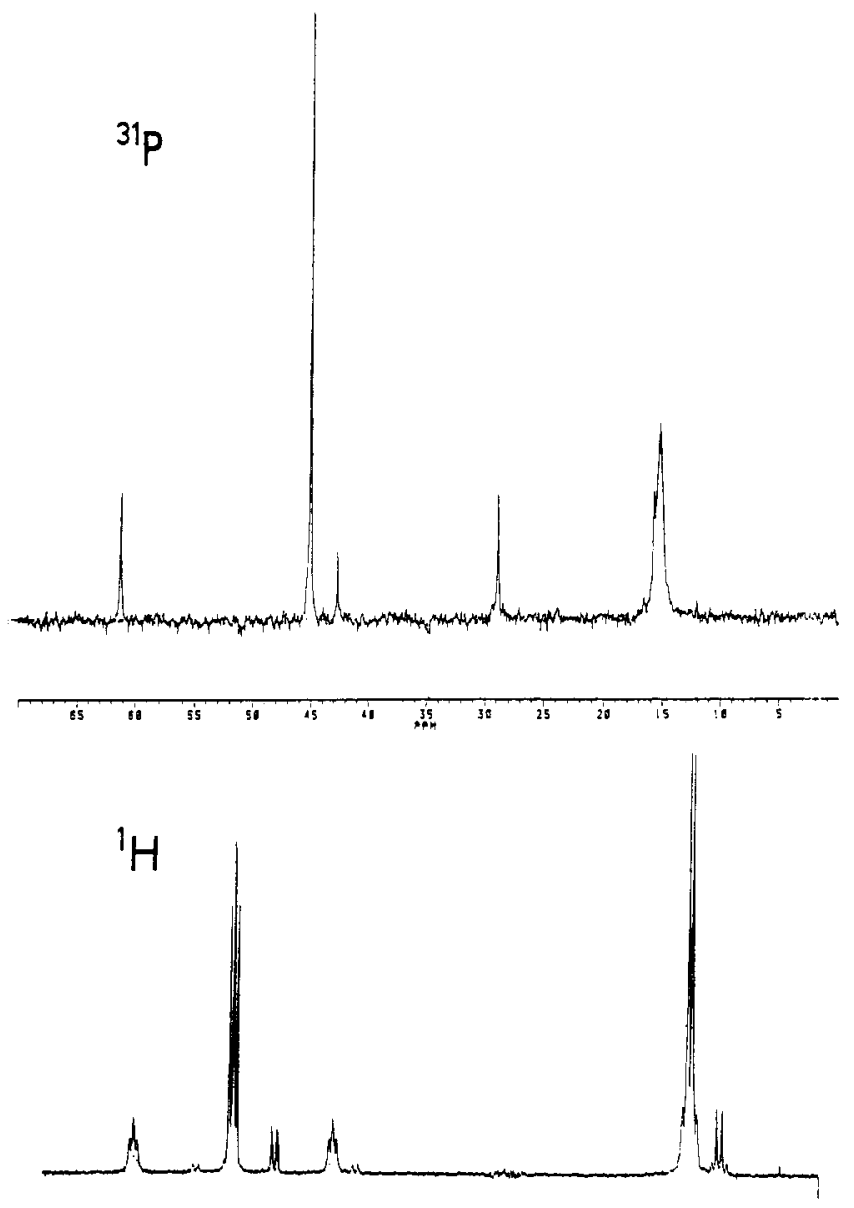

$\begin{array}{lllllllllll}-5 & -6 & -7 & -8 & -9 & -10 & -11 & -12 & -13 & -14 & -15\end{array}$

Figure 2. Bottom: hydridic region of the ${ }^{1} \mathrm{H}$ spectrum of a $\mathrm{CD}_{2} \mathrm{Cl}_{2}$ solution of the isomers $3 \mathbf{a}$ and $3 \mathbf{b}(200.13 \mathrm{MHz}, 273 \mathrm{~K})$. Top: ${ }^{31} \mathrm{P}$ spectrum of the same solution $(81.015 \mathrm{MHz}, 273 \mathrm{~K})$.

structure found in the solid state. In fact the values of the coupling constants indicate that only $\mathrm{P}_{\mathrm{a}}$ and $\mathrm{H}_{\mathrm{a}}$ are bound to $\mathrm{Pt}$. In particular the value of the $J_{\mathrm{H}-\mathrm{Pt}}$ of $\mathrm{H}_{\mathrm{a}}$ is typical of a hydride bridging a bond between platinum and another metal, ${ }^{9}$ while the $J_{\mathrm{P}-\mathrm{Pt}_{\mathrm{t}}}$ of $\mathrm{P}_{\mathrm{a}}$ is typical of phosphines directly bound to $\mathrm{Pt} .{ }^{10}$ Moreover, the values of all the $J_{\mathrm{H}-\mathrm{P}}$ are in the range usually found when the hydride and the phosphine are coordinated in the cis position, either in square-planar complexes ${ }^{11}$ or in trinuclear rhenium clus-

(9) See for instance: Ewing, P.; Farrugia, L. J.; Rycroft, D. S. Organometallics 1988, 7, 859 .

(10) Pregosin, P. S.; Kunz, R. W. ${ }^{31} \mathrm{P}$ and ${ }^{13} \mathrm{C}$ NMR of Transition Metal Phosphine Complexes. In NMR Basic Principles and Progress; Diehl, P., Fluck, E., Kosfeld, R., Eds.; Springer-Verlag: Berlin, 1979, Vol. 16.

(11) Kaesz, H. D.; Saillant, R. B. Chem. Rev. 1972, 72, 231.
Chart I. Some of the Possible Locations of the Phosphine and Hydride Ligands in the Complex $\left[\operatorname{Re}_{2} \mathrm{Pt}(\mu-\mathrm{H})_{2}\left(\mathrm{PPh}_{3}\right)_{2}(\mathrm{CO})_{8}\right]$
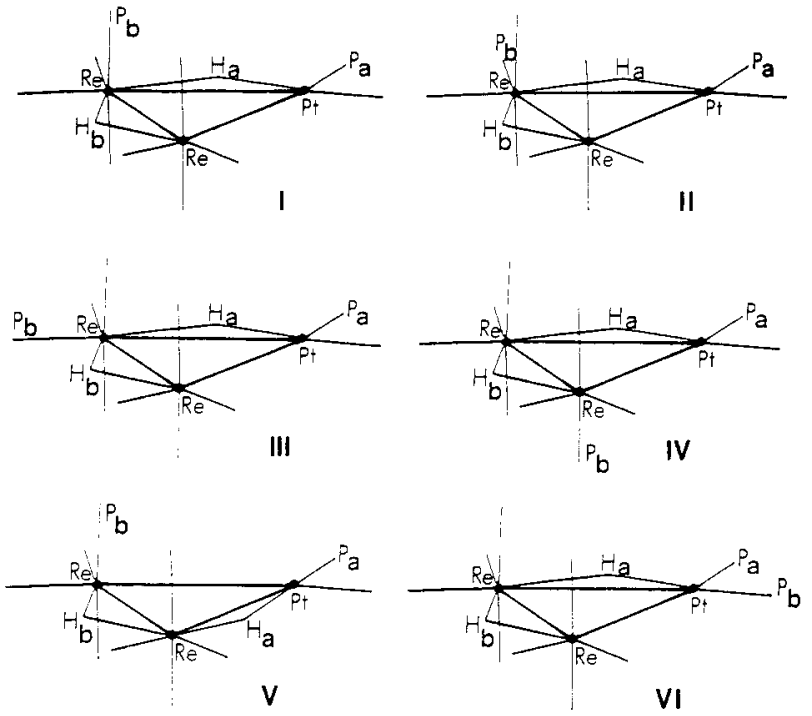

ters. $^{12}$ We assign therefore to $3 \mathbf{a}$ the structure $I$ in Chart I. ${ }^{13}$

The signal of $\mathrm{P}_{\mathrm{b}}$ shows an anomalous broadening at room temperature $\left(\Delta \nu_{1 / 2}=123 \mathrm{~Hz}\right)$. It sharpens at lower temperatures $\left(\Delta \nu_{1 / 2}=10 \mathrm{~Hz}\right.$ at $\left.213 \mathrm{~K}\right)$, but not to the extent of resolving the $\mathrm{Pt}$ satellites, which appear as shoulders of the main peak at $213 \mathrm{~K}$. It is not likely that this behavior is due to some sort of dynamic process. In fact (i) a mutual exchange of $\mathrm{P}_{a}$ and $\mathrm{P}_{b}$ is ruled out, because the signal of $\mathrm{P}_{\mathrm{a}}$ remains always sharp; (ii) the interconversion of the isomers $3 \mathbf{a}$ and $\mathbf{3 b}$ requires the interchange at the same rate of $\mathrm{P}_{a}(3 \mathrm{a})-\mathrm{P}_{\mathrm{a}}(3 \mathbf{b}), \mathrm{P}_{\mathrm{b}}(\mathbf{3 a})-\mathrm{P}_{\mathrm{b}}(\mathbf{3 b})$, $\mathrm{H}_{\mathrm{a}}(\mathbf{3 a})-\mathrm{H}_{\mathrm{a}}(\mathbf{3} \mathbf{b}), \mathrm{H}_{\mathrm{b}}(\mathbf{3 a})-\mathrm{H}_{\mathrm{b}}(\mathbf{3} \mathbf{b})$, and simulations performed to check this hypothesis showed that any fit of $\mathrm{P}_{b}(\mathbf{3 a})$ required significant broadening of all the other signals; (iii) the presence of a third isomer in very low amount (hidden exchange partner) would cause some perturbation also in the ${ }^{1} \mathrm{H}$ signals, and this is not the case; (iv) a dissociative process of the ligand itself is ruled out because on adding free $\mathrm{PPh}_{3}$ no additional broadening or change in the chemical shift was observed, and the hydrides retain their couplings with ${ }^{31} \mathrm{P}$ at every temperature, both with and without free $\mathrm{PPh}_{3}$. It is more likely, therefore, that the

12) (a) Beringhelli, T.; D'Alfonso, G.; Freni, M.; Ciani, G.; Sironi, A. Molinari, H. J. Chem. Soc., Dalton Trans, 1986, 2691. (b) Beringhelli, T.; D'Alfonso, G.; Freni, M.; Ciani, G. J. Organomet. Chem. 1986, 311, C51.

(13) In accord with this assignement, when some crystals, identical with those used for the X-ray structure determination, were dissolved in tetrahydrofuran- $d_{8}$ at $193 \mathrm{~K}$, the only signals observed in the ${ }^{1} \mathrm{H}$ NMR spectrum were those of $\mathbf{3 a}$ (at this temperature the exchange $\mathbf{3 a - 3} \mathbf{b}$ is frozen also on the chemical scale of time). 
broadening of the ${ }^{31} \mathrm{P}$ resonance is due to a short $T_{2}$, caused by scalar coupling with the quadrupolar rhenium isotopes. ${ }^{14}$

The ${ }^{1} \mathrm{H}$ and ${ }^{31} \mathrm{P}$ data of the isomer $3 \mathrm{~b}$ (Table II) are quite similar to those of $3 \mathbf{a}$, the main difference being in the small coupling constant between $\mathrm{H}_{\mathrm{a}}$ and $\mathrm{P}_{\mathrm{b}}(3.5 \mathrm{~Hz})$. This value could be consistent either with a ${ }^{3} J_{\mathrm{H}-\mathrm{P}}$ (as for instance in the structure IV of Chart I) or with a ${ }^{2} J_{\mathrm{H}-\mathrm{P}}($ trans) (structure III). However, no ${ }^{3} J_{\mathrm{H}-\mathrm{P}}$ was observed in $\left[\mathrm{Re}_{3}\right.$ $\left.(\mu-\mathrm{H})_{3}(\mathrm{CO})_{11}\left(\mathrm{PPh}_{3}\right)\right]$, for both the axial ${ }^{15}$ and equatorial ${ }^{16}$ isomers, while in $\left[\operatorname{Re}_{3}(\mu-\mathrm{H})_{2}(\mathrm{CO})_{10}\left(\mathrm{PPh}_{3}\right)_{2}\right]^{-12 \mathrm{~b}}$ where both the phosphine ligands are equatorial, a ${ }^{2} J_{\mathrm{H}-\mathrm{P}}($ trans) of 3 $\mathrm{Hz}$ was estimated. ${ }^{15}$ This strongly suggests that III is the structure of $\mathbf{3 b}$. A localized scrambling of the ligands of the $\operatorname{Re}(\mathrm{CO})_{3} \mathrm{PPh}_{3}$ moiety would therefore be responsible for the observed reversible isomerization.

Structure II in the Chart I can be ruled out because it would imply a ${ }^{2} J_{\mathrm{H}-\mathrm{P}}$ (trans) between $\mathrm{H}_{\mathrm{b}}$ and $\mathrm{P}_{\mathrm{b}}$. On the other hand, this structure would give rise to significant repulsive interactions between the phenyl groups of the two phosphines. Analogously, the structure V, which could be originated by a simple scrambling of $\mathrm{H}_{a}$ between the two $\mathrm{Re}-\mathrm{Pt}$ bonds, is ruled out since a trans- $\mathrm{H}-\mathrm{Pt}-\mathrm{P}$ location would imply a definitely higher $J_{\mathrm{H}-\mathrm{P}}$ (see below the value found for the isomer $3 \mathbf{c}$ ). Moreover, it has been already observed ${ }^{17}$ that in similar $(\mathrm{CO}) \mathrm{M}(\mu-\mathrm{H}) \mathrm{Pt}\left(\mathrm{PR}_{3}\right)$ fragments, the hydrido ligands lie cis to the phosphine, in order to reduce the repulsive nonbonding interaction between the carbonyl and the neighboring phosphine.

The exchange of the two isomers is slow, on both the ${ }^{1} \mathrm{H}$ and ${ }^{31} \mathrm{P}$ NMR time scale, up to $333 \mathrm{~K}$, as shown by the persistence of the fine structure of the hydridic resonances. At higher temperatures, in toluene- $d_{8}$, significant decomposition occurred. The existence of the exchange, however, could be clearly revealed by a ${ }^{1} \mathrm{H} 2 \mathrm{D}$ Exchange experiment at $294 \mathrm{~K}$.

The ratio $\mathbf{3 a} / \mathbf{3 b}$ is solvent dependent, varying, at room temperature, from about 3.7 in tetrahydrofuran to 3.2 in dichloromethane to 1.9 in toluene, as measured by ${ }^{1} \mathrm{H}$ NMR spectra. The isomer $3 \mathbf{a}$, therefore, seems to be favored as polarity of the solvent rises. The relative amount of $3 \mathbf{b}$ rises with the temperature, so that the two isomers are present in similar concentration at $353 \mathrm{~K}$, in toluene- $d_{8}$. The values of the ratio $3 \mathbf{a} / \mathbf{3 b}$ (the equilibrium constant of the reaction $3 \mathbf{b} \rightleftharpoons 3 \mathbf{a}$ ), measured in toluene- $d_{8}$ in the range $273-353 \mathrm{~K}$ allowed the estimation of the thermodynamic parameters of the equilibrium by a least-squares fit of $\ln K$ against $1 / T: \Delta H^{\ominus}=-1.72 \pm 0.04 \mathrm{kcal} \mathrm{mol}^{-1}$, $\Delta S^{\Theta}=-4.56 \pm 0.14 \mathrm{cal} \mathrm{mol}^{-1} \mathrm{~K}^{-1}$.

The Third Isomer. IR monitoring of the progress of the reaction between 1 and 2 at room temperature revealed the formation of an intermediate product $(3 \mathrm{c})$ that at temperatures lower than $273 \mathrm{~K}$ is stable enough to allow its complete spectroscopic characterization. The NMR spectra (recorded at $193 \mathrm{~K}$ ) showed that also in this species

(14) The contribution to the transverse relaxation rate of a nucleus with spin $1 / 2$ due to scalar coupling with a fast relaxing nucleus $Q$ with spin $S$ is given by $\left(1 / T_{2}\right)_{\mathrm{sc}}={ }^{4} /{ }_{3}\left(\pi^{2} J^{2} S(S+1) T_{1}(\mathrm{Q})\left[1+1 /(1+\Delta \omega)^{2} T_{1}\right.\right.$ $\left.\left.\left.(\mathrm{Q})^{2}\right)\right]\right\}$, where $\Delta \omega$ is the difference between the Larmor frequencies of the two nuclei. Rhenium quadrupolar relaxation times of $2.7 \times 10^{-8}$ and 4.4 $\times 10^{-8} \mathrm{~s}$ have been calculated for $\left[\operatorname{Re}_{3}(\mu-\mathrm{H})_{4}(\mathrm{CO})_{9}(\mathrm{NCMe})\right]^{-}$and $\left[\mathrm{Re}_{3}(\mu-\right.$ $\mathrm{H})(\mathrm{CO}) \mathrm{H}^{-}$, respectively. Beringhelli, T.; D'Alfonso, G.; Molinari, H. $J$ Chem. Soc., Dalton Trans. 1987, 2083. Beringhelli, T.; Molinari, H. Pastore, A. J. Chem. Soc., Dalton Trans. 1985, 1899. To account for the observed broadening, we must assume a ${ }^{31} \mathrm{P}-185 / 187 \mathrm{Re}$ coupling of the order of $\left(T_{1}(\mathrm{Re})\right)^{-1 / 2}$, that is, $10^{3}-10^{4} \mathrm{~Hz}$.

(15) Beringhelli, T.; D'Alfonso, G., unpublished results.

(16) Wei, C.; Garlaschelli, L.; Bau, R.; Koetzle, T. F. J. Organomet. Chem. 1981, 213, 63 .

(17) Farrugia, L. J.; Green, M.; Hankey, D. R. Murray, M.; Orpen, A G.; Stone, F. G. A. J. Chem. Soc., Dalton Trans. 1985, 177.

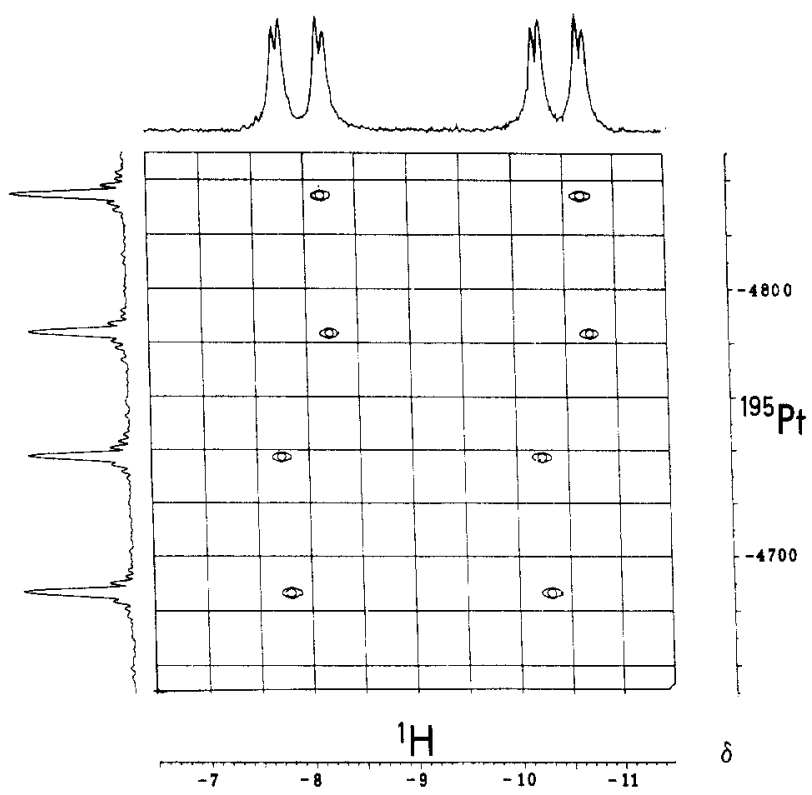

Figure 3. ${ }^{1} \mathrm{H}-{ }^{195} \mathrm{Pt} 2 \mathrm{D}$ reverse-correlation experiment for compound 3c optimized on $J_{\mathrm{H}_{\mathrm{a}}-\mathrm{Pt}}\left(\mathrm{CD}_{2} \mathrm{Cl}_{2}, 193 \mathrm{~K}\right)$. A total of $64 \mathrm{FIDs}$ of $1 \mathrm{~K}$ data points were recorded for each of the 128 increments of $t_{1}$ (spectral width in $F_{2} 1200 \mathrm{~Hz}$; spectral width in $F_{1} 6000 \mathrm{~Hz}$; relaxation delay $1 \mathrm{~s}$ ). Zero-filling was applied in $F_{1}$ before transformation performed without weighting functions in both dimensions. $F_{2}$ and $F_{1}$ projections of the $2 \mathrm{D}$ data matrix are shown in the figure.

two hydrides and two phosphine ligands are present, but with significant differences with respect to $\mathbf{3 a}$ and $\mathbf{3 b}$ (Table II). The ${ }^{31} \mathrm{P}$ NMR spectrum shows two resonances, mutually coupled, both with a high $J_{\mathrm{P}-\mathrm{Pt}}$, indicating that both the phosphines are bound to platinum. The lower field hydridic resonance, which shows a $J_{\mathrm{H}-\mathrm{Pt}}$ similar to those found in the $\operatorname{Pt}(\mu-\mathrm{H}) \mathrm{Re}$ moiety of $\mathbf{3 a}$ and $\mathbf{3 b}$, exhibits two $J_{\mathrm{H}-\mathrm{p}}$ : one is similar to those of $3 \mathbf{a}$ and $\mathbf{3 b}$, while the other one is markedly higher, as expected for a $J_{\text {trans }}$ with respect to a $J_{\text {cis }}$, in H-Pt-P systems. The hydridic resonance at higher field (indicative of a bridging coordination between two rhenium atoms) does not show any resolved coupling to $\mathrm{P}$ or $\mathrm{Pt}$.

The structure VI in the Chart I can therefore be suggested for 3c, as expected for the species formed as soon as $\left[\mathrm{Pt}\left(\mathrm{PPh}_{3}\right)_{2}\left(\mathrm{C}_{2} \mathrm{H}_{4}\right)\right]$ reacts with the rhenium-unsaturated molecule. The reaction could be described as the substitution of ethylene by an ethylene-like molecule, even if the reaction product lacks the "unsaturated" four-center four electron $(4 \mathrm{c}-4 \mathrm{e}) \operatorname{Re}(\mu-\mathrm{H})_{2} \operatorname{Re}$ system, which has been converted in two $3 c-2 e \operatorname{Re}(\mu-\mathrm{H}) \mathrm{M}$ bonds, because of the insertion of the $\mathrm{PtP}_{2}$ fragment into a $\operatorname{Re}(\mu-\mathrm{H}) \mathrm{Re}$ bond.

Selective decoupling $\left.{ }^{1} \mathrm{H} \mid{ }^{31} \mathrm{P}\right\}$ showed that the low-field signal in the ${ }^{31} \mathrm{P}$ spectrum is due to the phosphine cis. It is noteworthy that $P_{b}$, trans to the bridging hydride, shows a $J_{\mathrm{Pt}-\mathrm{P}}$ markedly higher than $\mathrm{P}_{\mathrm{a}}$, trans to the $\mathrm{Pt}-\mathrm{Re}$ direct bond. This suggests a higher trans influence of the $\mathbf{M}-\mathbf{M}^{\prime}$ bond with respect to the $\mathrm{M}(\mu-\mathrm{H}) \mathrm{M}^{\prime}$ one. In accord with this, in the case of the complex $\left[\mathrm{Ru}_{4}(\mu-\mathrm{H})_{4}(\mathrm{CO})_{12}\right]$ it was found ${ }^{18}$ that the $\mathrm{Ru}-\mathrm{CO}$ bonds opposite $\mathrm{Ru}-\mathrm{Ru}$ interactions were longer than those opposite $\mathrm{Ru}(\mu-\mathrm{H}) \mathrm{Ru}$ bonds. This was assumed to imply that the $R u-R u$ bond is a better " $\pi$ ligand" than the $\operatorname{Ru}(\mu-\mathrm{H}) \mathrm{Ru}$ one.

2D Reverse Correlation Experiments. Heteronuclear NMR 2D correlation experiments performed in the reverse

(18) Wilson, R. D.; Wu, S. M.; Love, R. A.; Bau, R. Inorg. Chem. 1978, 17, 1271 . 


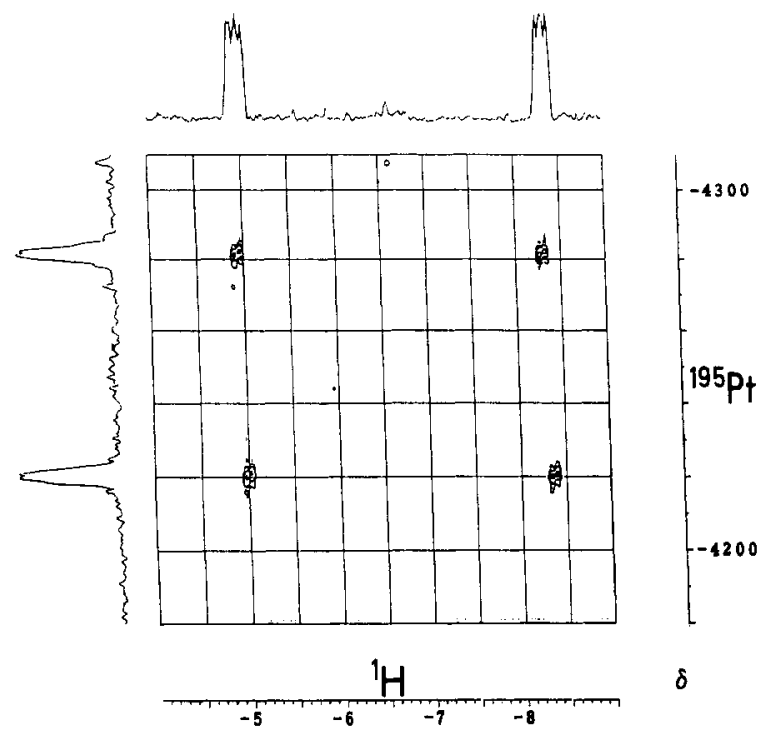

Figure 4. ${ }^{1} \mathrm{H}-{ }^{195} \mathrm{Pt} 2 \mathrm{D}$ reverse-correlation experiment optimized on $J_{\mathrm{H}_{2}-\mathrm{Pt}}$ of compound $3 \mathrm{a}\left(\mathrm{CD}_{2} \mathrm{Cl}_{2}, 294 \mathrm{~K}\right)$. A total of $64 \mathrm{FIDs}$ of $1 \mathrm{~K}$ data points were recorded for each of the 256 increments of $t_{1}$ (spectral width in $F_{2} 2000 \mathrm{~Hz}$; spectral width in $F_{1} 5000 \mathrm{~Hz}$; relaxation delay $1 \mathrm{~s}$ ). Lorentz-Gauss weighting functions were applied in both dimensions after zero-filling in $F_{1} . F_{2}$ and $F_{1}$ projections of the $2 \mathrm{D}$ data matrix are shown in the figure.

mode ${ }^{19}$ have been employed to detect ${ }^{195} \mathrm{Pt}$ resonances of compounds $3 \mathbf{a}, \mathbf{3 b}$, and $\mathbf{3} \mathbf{c}$, directly on the reaction mixtures in a 5-mm-o.d. NMR tube (typically 0.04-0.06 M solutions in $\mathrm{CD}_{2} \mathrm{Cl}_{2}$ ). This technique, which relies on the transfer of polarization from a sensitive nucleus $\mathrm{S}$ to an insensitive nucleus I, allows a significant improvement in sensitivity (theoretically of the order of $\left(\gamma_{S} / \gamma_{I}\right)^{5 / 2}$ with respect to the direct observation and of the order of $\left(\gamma_{\mathrm{S}} / \gamma_{\mathrm{I}}\right)^{3 / 2}$ with respect to the INEPT sequence).

In the sequence used (see Experimental Section) the delay between the first two pulses $\left(D_{2}=1 /\left(2 J_{\mathrm{H}-\mathrm{Pt}}\right)\right)$ allows the choice of the species to be detected in a mixture or, within the same molecule, of the coupling to be employed to establish the correlations.

Figures 3-5 show the results obtained in experiments optimized according to ${ }^{1} J_{\mathrm{H}-\mathrm{Pt}}$ for $\mathrm{H}_{\mathrm{a}}$ in compounds $3 \mathbf{c}, 3 \mathbf{a}$, and $3 \mathbf{b}$, respectively, while the experiment in Figure 6 was optimized for ${ }^{2} J_{\mathrm{H}-\mathrm{Pt}}$ of $\mathrm{H}_{\mathrm{b}}$ in compound $\mathbf{3 a}$.

The sequence employed gives, in the $F_{1}$ dimension, the spectrum of ${ }^{195} \mathrm{Pt}$ decoupled from ${ }^{1} \mathrm{H}$ : the $\mathrm{Pt}$ resonances for all three isomers appear therefore as doublets of doublets, due to the couplings with ${ }^{31} \mathrm{P}$. The ${ }^{195} \mathrm{Pt}$ chemical shifts and couplings are reported in Table II.

This technique also permits improved resolution of the passive couplings of both ${ }^{1} \mathrm{H}$ and ${ }^{195} \mathrm{Pt}$ and, from the pattern of the cross peaks, attainment of information on their relative signs (being ${ }^{195} \mathrm{Pt}$ decoupled from ${ }^{1} \mathrm{H}$ in $F_{1}$, the sign of the active couplings is not definable from these experiments). The analysis of these features, together with ${ }^{1} \mathrm{H}\left\{^{31} \mathrm{P}\right\}$ selective decoupling experiments, allows the following remarks.

The irradiations of the low-field $\mathrm{Pt}$ satellites of both $\mathrm{P}_{\mathrm{a}}$ and $\mathrm{P}_{\mathrm{b}}$ resonances in the ${ }^{31} \mathrm{P}$ spectrum of compound $3 \mathrm{c}$ at $200 \mathrm{~K}$ affected the low-field satellite of $\mathrm{H}_{\mathrm{a}}$, thus indicating that in $3 c^{1} J_{\mathrm{Pt}-\mathrm{H}}$ for the hydride $\mathrm{H}_{\mathrm{a}}$ and ${ }^{1} J_{\mathrm{Pt}-\mathrm{P}}$ for both $\mathrm{P}_{\mathrm{a}}$ and $P_{b}$ are of the same sign. In similar compounds it was proved that ${ }^{1} J_{\mathrm{pt}-\mathrm{H}}$ and ${ }^{1} J_{\mathrm{Pt}-\mathrm{P}}$ are positive. ${ }^{20}$

(19) (a) Bodenhausen, G.; Ruben, D. Chem. Phys. Lett. 1980, 69, 185. (b) Minoretti, A.; Aue, W. P.; Reinhold, M.; Ernst, R. R. J. Magn. Reson. 1980, 40, 175. (c) Bax, A.; Griffey, R. H.; Hawkins, B. L. J. Magn. Reson. $1983,55,301$.

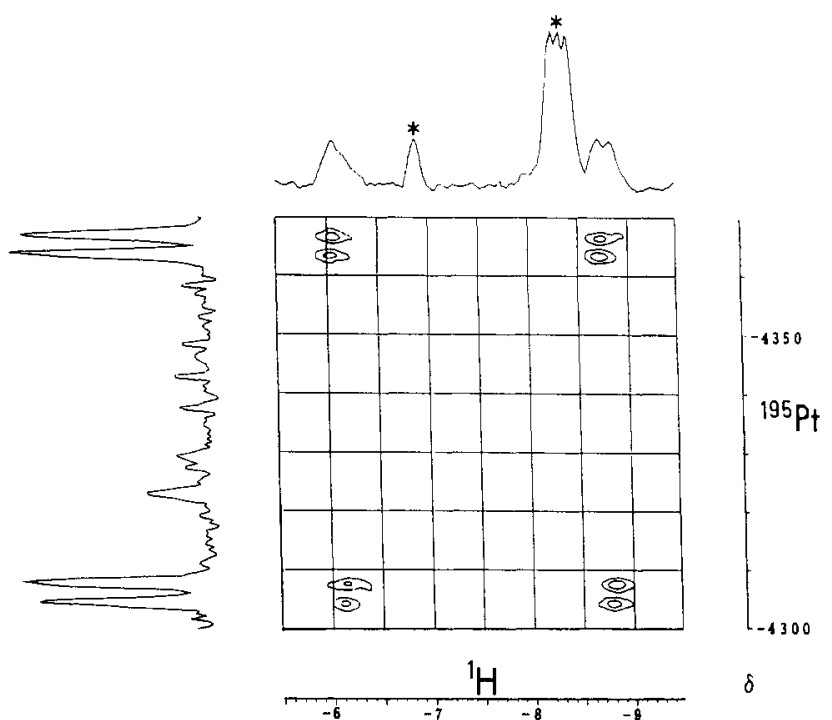

Figure 5. ${ }^{1} \mathrm{H}-{ }^{195} \mathrm{Pt} 2 \mathrm{D}$ reverse-correlation experiment optimized on $J_{\mathrm{H}_{\mathrm{a}}-\mathrm{Pt}}$ of compound $3 \mathbf{b}\left(\mathrm{CD}_{2} \mathrm{Cl}_{2}, 294 \mathrm{~K}\right)$. A total of $128 \mathrm{FIDs}$ of $1 \mathrm{~K}$ data points were recorded for each of the 256 increments of $t_{1}$ (spectral width in $F_{2} 2000 \mathrm{~Hz}$; spectral width in $F_{1} 5000 \mathrm{~Hz}$; relaxation delay $1 \mathrm{~s})$. Lorentz-Gauss weighting functions were applied in both dimensions after zero-filling in $F_{1}$. The figure shows only the part of the data matrix related to compound $3 \mathrm{~b}$. The $F_{2}$ projection, displayed on the top, shows also, marked with an asterisk, the high-field ${ }^{195} \mathrm{Pt}$ sideband of $\mathrm{H}_{\mathrm{a}}$ in $3 \mathbf{a}$ and some residual magnetization of its central band.

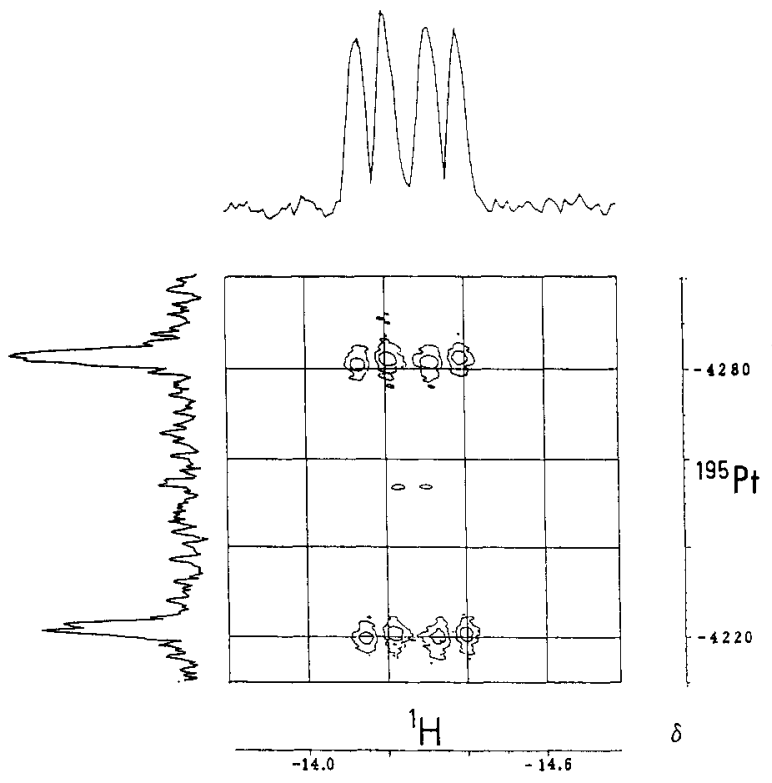

Figure 6. ${ }^{1} \mathrm{H}-{ }^{195} \mathrm{Pt} 2 \mathrm{D}$ reverse-correlation experiment optimized on $J_{\mathrm{H}}-\mathrm{Pt}$ of compound $3 \mathrm{a}\left(\mathrm{CD}_{2} \mathrm{Cl}_{2}, 294 \mathrm{~K}\right)$. A total of $32 \mathrm{FIDs}$ of $1 \mathrm{~K}$ data points were recorded for each of the 256 increments of $t_{1}$ (spectral width in $F_{2} 2000 \mathrm{~Hz}$; spectral width in $F_{1} 5000 \mathrm{~Hz}$; relaxation delay $0.5 \mathrm{~s}$ ). Lorentz-Gauss weighting functions were applied in both dimensions after zero-filling in $F_{1} . F_{2}$ and $F_{1}$ projections of the $2 \mathrm{D}$ matrix are shown in the figure.

The pattern of the cross peaks obtained for 3c (Figure 3 ) indicates that ${ }^{2} J_{\mathrm{H}-\mathrm{P}}$ between $\mathrm{H}_{\mathrm{a}}$ and $\mathrm{P}_{\mathrm{a}}$ has a sign opposite to all the others, since the low-frequency doublet in the ${ }^{195} \mathrm{Pt}$ dimension is related to the low-frequency doublet of each satellite in the ${ }^{1} \mathrm{H}$ dimension (that is for $\mathrm{P}_{\mathrm{b}}{ }^{2} J$ with $\mathrm{H}_{\mathrm{a}}$ and ${ }^{1} J$ with $\mathrm{Pt}$ of the same sign), but the

(20) Pregosin, P. S. Platinum NMR Spectroscopy. In Annual Reports on NMR Spectroscopy; Academic Press: London, 1986; Vol. 17, and references therein. 
low-frequency component within each ${ }^{195} \mathrm{Pt}$ doublet corresponds to the high-frequency component in the ${ }^{1} \mathrm{H}$ doublet. Different signs for the two ${ }^{2} J_{\mathrm{H}-\mathrm{P}}$ have been reported for compounds where the cis- $\mathrm{HPtP} \mathrm{P}_{2}$ moiety $(\mathrm{P}=$ ligand with phosphorus as donor atom) is present. ${ }^{21}$

The experiments shown in Figures 4 and 5 were performed at $294 \mathrm{~K}$ and are related to the correlation of $\mathrm{H}_{\mathrm{a}}$ with $\mathrm{Pt}$ in compounds $3 \mathbf{a}$ and $\mathbf{3 b}$, respectively. All the passive couplings of ${ }^{195} \mathrm{Pt}$ with ${ }^{31} \mathrm{P}$ are clearly resolved and measurable at room temperature. On the contrary, in the normal 1D ${ }^{31} \mathrm{P}$ spectrum of the solution (Figure 2), even at $273 \mathrm{~K}$ the $\mathrm{P}_{\mathrm{b}}$ resonance was extremely broad for isomer $3 a$ and overlapping with the $\mathrm{P}_{\mathrm{b}}$ resonance of isomer $3 \mathbf{b}$, so that the couplings with $\mathrm{Pt}$ were not resolved for both the signals. Moreover the $\mathrm{Pa}-\mathrm{Pt}$ satellites of $3 \mathbf{b}$ were not present in this spectrum, and at $294 \mathrm{~K}$ even the central resonance was not observable, in $\mathrm{CD}_{2} \mathrm{Cl}_{2}$ solution. The measured values are reported in Table II. The remarkable difference in ${ }^{2} J$ of $\mathbf{P}_{b}$ with $\mathrm{Pt}$ observed for $3 \mathbf{a}$ and $\mathbf{3 b}$ (where $\mathrm{P}_{\mathrm{b}}$ is, respectively, in cis or in trans position to the $\mathrm{Re}-\mathrm{H}-\mathrm{Pt}$ bond) reminds us of that observed in $\mathrm{Pt}$ dinuclear compounds for phosphine ligands bound cis or trans to $\mathrm{Pt} .{ }^{22}$

The isomers $\mathbf{3 a}$ and $\mathbf{3 b}$ show the same pattern of cross peaks, which is different from that of $3 c$. Since in these compounds $\mathrm{H}_{\mathrm{a}}$ and ${ }^{195} \mathrm{Pt}$ retain the couplings with $\mathrm{P}_{\mathrm{a}}$, which have been shown in $3 \mathrm{c}$ to have opposite signs, the observed pattern is consistent only with $\mathrm{P}_{\mathrm{b}}$ couplings, ${ }^{2} J$ with $\mathrm{H}_{\mathrm{a}}$ and ${ }^{2} J$ with $\mathrm{Pt}$, having the same sign.

The experiment shown in Figure 6 is related to the correlation of $\mathrm{H}_{\mathrm{b}}$ of $3 \mathrm{a}$ with $\mathrm{Pt}$ and allows the measurement of a small coupling of this hydride with $\mathrm{P}_{\mathrm{a}}$ (ca. $3 \mathrm{~Hz}$ ), not resolved even in ${ }^{1} \mathrm{H}$ spectra.

The overall pattern of the cross peaks in the experiments related to $3 a$ indicates that ${ }^{2} J$ of $\mathrm{H}_{b}$ with $\mathrm{P}_{b}$ has the same sign of the other ${ }^{2} J$ couplings related to $\mathrm{P}_{b}$, while ${ }^{3} J$ of $\mathrm{H}_{\mathrm{b}}$ with $\mathrm{P}_{\mathrm{a}}$ has a sign opposite to ${ }^{1} J$ of $\mathrm{Pt}$ with $\mathrm{P}_{\mathrm{a}}$.

\section{Experimental Section}

The reactions were performed under nitrogen, using the Schlenk technique, and solvents deoxygenated and dried by standard methods. Literature methods were used for the synthesis of $\left[\mathrm{Pt}\left(\mathrm{PPh}_{3}\right)_{2}\left(\mathrm{C}_{2} \mathrm{H}_{4}\right)\right]^{23}$ and $\left[\mathrm{Re}_{2}(\mu-\mathrm{H})_{2}(\mathrm{CO})_{8}\right] .{ }^{24}$ Infrared spectra were recorded in 0.1-mm CaF ${ }_{2}$ cells on a Perkin-Elmer 781 grating spectrophotometer, equipped with a data station using PE780 software. Mass spectra were obtained on a VG 7070EQ spectrometer. The FAB spectrum was performed from a 3-nitrobenzyl alcohol matrix, by using Xe atoms.

Synthesis of $\left[\operatorname{Re}_{2} \mathbf{P t}(\mu-\mathbf{H})_{2}(\mathbf{C O})_{8}\left(\mathbf{P P h}_{3}\right)_{2}\right]$. A sample $(300 \mathrm{mg}$, $0.501 \mathrm{mmol})$ of $\left[\operatorname{Re}_{2}(\mu-\mathrm{H})_{2}(\mathrm{CO})_{8}\right]$, dissolved in $\mathrm{CH}_{2} \mathrm{Cl}_{2}(20 \mathrm{~mL})$, was treated at room temperature with $\left[\mathrm{Pt}\left(\mathrm{PPh}_{3}\right)_{2}\left(\mathrm{C}_{2} \mathrm{H}_{4}\right)\right](390 \mathrm{mg}$, $0.522 \mathrm{mmol}$ ). The color turned immediately from yellow to orange-red. No evolution of $\mathrm{CO}$ or $\mathrm{H}_{2}$ was revealed by gas chromatography. The progress of the reaction was monitored by TLC and IR spectroscopy. After $3 \mathrm{~h}$, the solvent was removed under reduced pressure, and the residue was treated with a $\mathrm{CH}_{2} \mathrm{Cl}_{2}$ / $\mathrm{C}_{6} \mathrm{H}_{14}$ mixture $(1 / 2 \mathrm{v} / \mathrm{v}, 5 \mathrm{~mL})$, giving a yellow precipitate of $\left[\operatorname{Re}_{2} \mathrm{Pt}(\mu-\mathrm{H})_{2}(\mathrm{CO})_{8}\left(\mathrm{PPh}_{3}\right)_{2}\right]$ and a red-brown solution. The solid was washed three times with the same mixture and then dried in vacuum $(410 \mathrm{mg}, 0.311 \mathrm{mmol})$. The solutions were collected and eluted on a preparative TLC plate $\left(\mathrm{SiO}_{2}, 2 \mathrm{~mm}\right)$ with the same

(21) See for instance: Azizian, H.; Dixon, K. R.; Eaborn, C.; Pidcock, A.; Shuaib, N. M.; Vinaixa, J. J. Chem. Soc., Chem. Commun. 1982, 1020. Bars, O.; Braunstein, P.; Geoffroy, G. L.; Metz, B. Organometallics 1986. $5,2021$.

(22) Goodfellow, R. J. Group VIII Transition Metals. In Multinuclear NMR; Mason, J., Ed.; Plenum Press: New York, 1988, and references therein.

(23) Nagel, U. Chem. Ber. 1982, 115, 1998.

(24) Andrews, M. A.; Kirtley, S. W.; Kaesz, H. D. Inorg. Chem. 1977, 16,1556 .
Table III. Crystal Data for $\left[\operatorname{Re}_{2} \mathrm{Pt}(\mu-\mathrm{H})_{2}(\mathrm{CO})_{8}\left(\mathrm{PPh}_{3}\right)_{2}\right](3)$

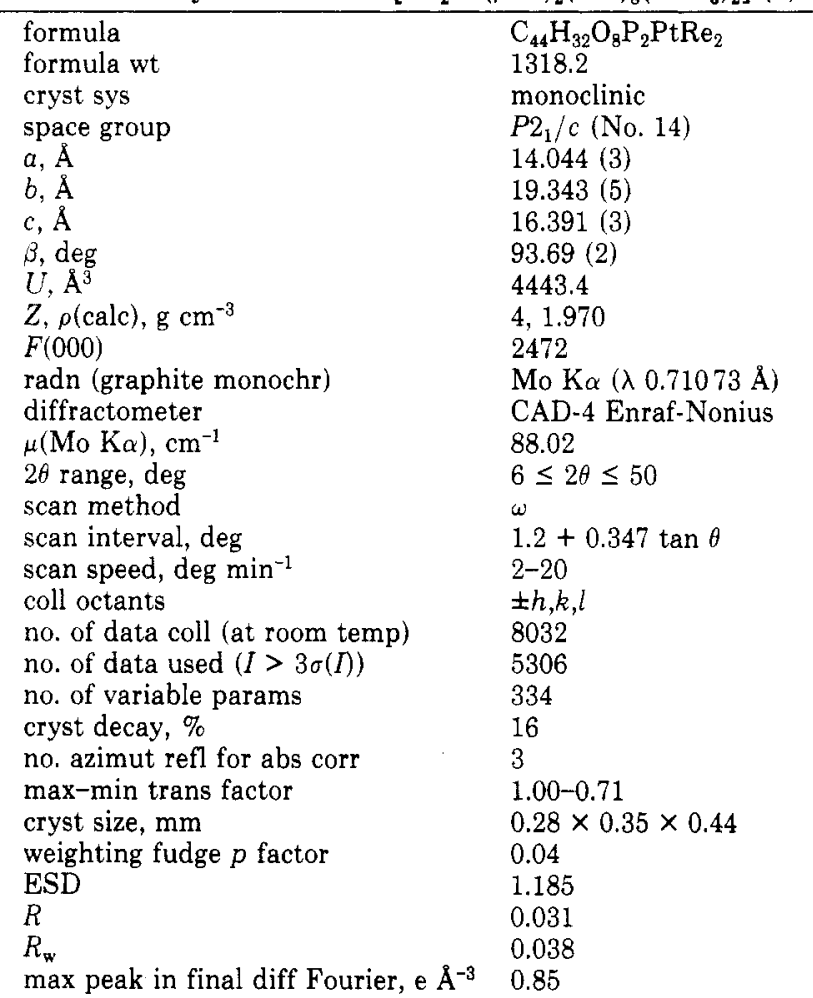

$$
\begin{aligned}
& \operatorname{ESD}=\left(\sum w\left(\left|F_{\mathrm{o}}\right|-k\left|F_{\mathrm{c}}\right|\right)^{2} /\left(N_{\mathrm{obs}}-N_{\text {var }}\right)\right)^{1 / 2} \\
& w=4\left|F_{\mathrm{o}}\right|^{2} / \sigma^{2}\left(\left|F_{\mathrm{o}}\right|^{2}\right), \text { where } \sigma\left(\left|F_{\mathrm{o}}\right|^{2}\right)=\left(\sigma^{2}(I)+(p I)^{2}\right)^{1 / 2} / L p \\
& R=\sum\left|F_{\mathrm{o}}\right|-k\left|F_{\mathrm{d}}\right| / \sum\left|F_{\mathrm{o}}\right| \\
& R_{\mathrm{w}}=\left(\sum w\left(\left|F_{\mathrm{o}}\right|-k\left|F_{\mathrm{c}}\right|\right)^{2} / \sum w\left|F_{\mathrm{o}}\right|^{2}\right)^{1 / 2}
\end{aligned}
$$

mixture, affording, after extraction with $\mathrm{CH}_{2} \mathrm{Cl}_{2}$, further $110 \mathrm{mg}$ $(0.083 \mathrm{mmol})$ of pure $\left[\mathrm{Re}_{2} \mathrm{Pt}(\mu-\mathrm{H})_{2}(\mathrm{CO})_{8}\left(\mathrm{PPh}_{3}\right)_{2}\right]$; overall isolated yields $79 \%$. Anal. Calcd for $\mathrm{C}_{44} \mathrm{H}_{32} \mathrm{O}_{8} \mathrm{P}_{2} \mathrm{PtRe}_{2}$ : C, $40.05 ; \mathrm{H}, 2.43$. Found: C, $40.0 ; \mathrm{H}, 2.22$. IR $\nu(\mathrm{CO}) 2077 \mathrm{~m}, 2021 \mathrm{vs}, 1980 \mathrm{~s}, 1970$ $\mathrm{sh}, 1934 \mathrm{~ms}, 1923 \mathrm{~ms} \mathrm{~cm}^{-1}\left(\mathrm{CH}_{2} \mathrm{Cl}_{2}\right)$. Upon heating, the solid compound darkened starting from $413 \mathrm{~K}$.

Synthesis of the Isomer 3c. A sample of $\left[\operatorname{Re}_{2}(\mu-\mathrm{H})_{2}(\mathrm{CO})_{8}\right]$ (16 mg, $0.0267 \mathrm{mmol})$ dissolved in $\mathrm{CH}_{2} \mathrm{Cl}_{2}(3 \mathrm{~mL})$ and cooled at $273 \mathrm{~K}$ in an ice bath was treated with $\left[\mathrm{Pt}\left(\mathrm{PPh}_{3}\right)_{2}\left(\mathrm{C}_{2} \mathrm{H}_{4}\right)\right](27 \mathrm{mg}$, $0.0362 \mathrm{mmol}$ ). The solution became immediately orange-red. After $30 \mathrm{~min}$ IR monitoring (using cells cooled in a freezer) showed the quantitative formation of the new species: $\nu(\mathrm{CO}) 2088 \mathrm{~m}, 2051$ $\mathrm{ms}, 1992 \mathrm{vs}, 1953 \mathrm{~s}, 1913 \mathrm{~m} \mathrm{~cm}^{-1}$. When the solution in the IR cells was allowed to reach room temperature, the bands of $3 c$ were replaced by those of the equilibrium mixture $3 \mathbf{a}-\mathbf{3 b}$ in about 90 min. The same reaction was performed in a NMR tube, treating $\left[\mathrm{Re}_{2}(\mu-\mathrm{H})_{2}(\mathrm{CO})_{8}\right](15 \mathrm{mg}, 0.025 \mathrm{mmol})$ suspended in $\mathrm{CD}_{2} \mathrm{Cl}_{2}$ at $193 \mathrm{~K}$ with $\left[\mathrm{Pt}\left(\mathrm{PPh}_{3}\right)_{2}\left(\mathrm{C}_{2} \mathrm{H}_{4}\right)\right](20 \mathrm{mg}, 0.027 \mathrm{mmol})$. The sample was kept at $273 \mathrm{~K}$ for $15 \mathrm{~min}$, and then ${ }^{1} \mathrm{H}$ and ${ }^{31} \mathrm{P}$ NMR spectra were recorded at $193 \mathrm{~K}$, showing the almost quantitative formation of $3 \mathbf{c}$.

NMR Measurements. All the NMR measurements were performed on a Bruker $\mathrm{AC} 200$ spectrometer operating at 200.13 $\mathrm{MHz}$ for ${ }^{1} \mathrm{H}$ and $81.015 \mathrm{MHz}$ for ${ }^{31} \mathrm{P}$. The probe head used was a $5-\mathrm{mm}$ probe with the inner coils tuned on the ${ }^{1} \mathrm{H}$ frequency and outer coils tunable in the range of ${ }^{109} \mathrm{Ag}-{ }^{31} \mathrm{P}$ frequencies. The $90^{\circ}$ pulse for proton and phosphorus were 4.7 and $9 \mu \mathrm{s}$, respectively. Variable-temperature experiments were performed under the active control of a B-VT 1000 unit, supplied by the manufacturers of the spectrometer.

Selective ${ }^{1} \mathrm{H}\left\{{ }^{13} \mathrm{P}\right\}$ decoupling and $2 \mathrm{D}$ heteronuclear reversecorrelation experiments were performed with the use of a second synthesizer and of a B-SV3 decoupling unit, equipped with selective preamplifiers for ${ }^{31} \mathrm{P}$ and ${ }^{195} \mathrm{Pt}$ allowing up to $80 \mathrm{~W}$ of decoupling power. Computer-controlled phase shifters were used to control the phases of the I nucleus pulses as required by the pulse sequence used ${ }^{19 c}\left[\pi / 2\left({ }^{1} \mathrm{H}\right)-D_{2}-\pi / 2\left({ }^{195} \mathrm{Pt}\right)-t_{1 / 2^{-}} \pi\left({ }^{1} \mathrm{H}\right)-t_{1 / 2^{-}}\right.$ $\pi / 2\left({ }^{195} \mathrm{Pt}\right)$-acq $\left.\left({ }^{1} \mathrm{H}\right)\right]$. The $90^{\circ}$ pulse through the B-SV3 unit for ${ }^{195} \mathrm{Pt}$ was $35 \mu \mathrm{s}$. Other experimental details concerning $2 \mathrm{D}$ reverse experiments are reported in the figure captions. The estimated 
Table IV. Final Positional Parameters for $\left[\operatorname{Re}_{2} \mathrm{Pt}(\mu-\mathrm{H})_{2}(\mathrm{CO})_{8}\left(\mathrm{PPh}_{3}\right)_{2}\right](3)$

\begin{tabular}{|c|c|c|c|}
\hline atom & $x$ & $y$ & $z$ \\
\hline $\mathrm{Pt}$ & $0.15122(2)$ & $0.15783(2)$ & $0.16683(2)$ \\
\hline $\operatorname{Re}(1)$ & $0.33146(2)$ & $0.10110(2)$ & $0.12013(2)$ \\
\hline $\operatorname{Re}(2)$ & $0.27311(2)$ & $0.26121(2)$ & $0.11709(2)$ \\
\hline$P(1)$ & $0.0371(2)$ & $0.0816(1)$ & $0.2100(1)$ \\
\hline $\mathrm{P}(2)$ & $0.4383(2)$ & $0.0941(1)$ & $0.2463(1)$ \\
\hline $\mathrm{C}(1)$ & $0.0651(6)$ & $0.2306(5)$ & $0.1397(6)$ \\
\hline $\mathrm{O}(1)$ & $0.0060(5)$ & $0.2679(4)$ & $0.1258(5)$ \\
\hline $\mathrm{C}(2)$ & $0.4376(6)$ & $0.0946(5)$ & $0.0530(5)$ \\
\hline $\mathrm{O}(2)$ & $0.5014(5)$ & $0.0933(4)$ & $0.0117(4)$ \\
\hline $\mathrm{C}(3)$ & $0.3210(6)$ & $0.0030(5)$ & $0.1287(6)$ \\
\hline$O(3)$ & $0.3153(5)$ & $-0.0560(3)$ & $0.1335(5)$ \\
\hline $\mathrm{C}(4)$ & $0.2426(6)$ & $0.0948(5)$ & $0.0246(5)$ \\
\hline $\mathrm{O}(4)$ & 0.1937 (5) & 0.0875 (4) & -0.0331 \\
\hline$C(5)$ & $0.3824(7)$ & $0.3160(5)$ & $0.0916(6)$ \\
\hline $\mathrm{O}(5)$ & $0.4468(5)$ & $0.3481(4)$ & $0.0777(5)$ \\
\hline $\mathrm{C}(6)$ & $0.1932(7)$ & $0.3416(5)$ & $0.1171(6)$ \\
\hline$O(6)$ & $0.1471(5)$ & $0.3914(3)$ & $0.1151(5)$ \\
\hline$C(7)$ & $0.3005(7)$ & $0.2714(5)$ & $0.2365(6)$ \\
\hline $\mathrm{O}(7)$ & $0.3126(6)$ & $0.2813(4)$ & 0.3053 \\
\hline$C(8)$ & $0.2295(7)$ & $0.2481(5)$ & $0.0014(6)$ \\
\hline$O(8)$ & $0.1974(6)$ & $0.2433(4)$ & -0.0645 \\
\hline $\mathrm{C}(111)$ & $0.0053(6)$ & $0.0963(4)$ & $0.3150(5)$ \\
\hline $\mathrm{C}(112)$ & $0.0148(7)$ & $0.1616(5)$ & $0.3477(6)$ \\
\hline$C(113)$ & $-0.0149(9)$ & $0.1762(6)$ & $0.4244(7)$ \\
\hline$C(114)$ & $-0.0541(8)$ & $0.1232(6)$ & $0.4692(7)$ \\
\hline$C(115)$ & -0.0622 & 0.0584 & $0.4365(6)$ \\
\hline$C(116)$ & $-0.0333(7)$ & $0.0443(5)$ & $0.3596(6)$ \\
\hline $\mathrm{C}(121)$ & $-0.0742(6)$ & 0.0964 (4) & $0.1477(5)$ \\
\hline $\mathrm{C}(122)$ & $-0.0691(7)$ & $0.0913(6)$ & $0.0636(6)$ \\
\hline $\mathrm{C}(123)$ & $-0.1505(9)$ & $0.1043(6)$ & $0.0124(8)$ \\
\hline $\mathrm{C}(124)$ & $-0.2323(9)$ & $0.1216(7)$ & $0.0459(8)$ \\
\hline$C(125)$ & -0.2381 & $0.1271(7)$ & $0.1286(8)$ \\
\hline$C(126)$ & $-0.1564(7)$ & $0.1149(5)$ & $0.1790(6)$ \\
\hline $\mathrm{C}(131)$ & $0.0562(6)$ & $-0.0115(5)$ & $0.2076(5)$ \\
\hline$C(132)$ & $-0.0097(7)$ & $-0.0566(6)$ & $0.1708(6)$ \\
\hline $\mathrm{C}(133)$ & $0.0059(9)$ & $-0.1265(7)$ & $0.1747(8)$ \\
\hline$C(134)$ & $0.0844(8)$ & $-0.1524(6)$ & $0.2141(7)$ \\
\hline$C(135)$ & $0.1513(9)$ & $-0.1096(6)$ & $0.2516(7)$ \\
\hline$C(136)$ & $0.1378(7)$ & $-0.0383(5)$ & $0.2479(6)$ \\
\hline$C(211)$ & $0.4911(6)$ & $0.1733(5)$ & $0.2897(5)$ \\
\hline $\mathrm{C}(212)$ & $0.4946(8)$ & $0.1881(6)$ & $0.3709(7)$ \\
\hline$C(213)$ & $0.538(1)$ & $0.2476(7)$ & $0.4025(9)$ \\
\hline $\mathrm{C}(214)$ & $0.574(1)$ & $0.2929(8)$ & $0.3505(9)$ \\
\hline $\mathrm{C}(215)$ & $0.574(1)$ & $0.2815(8)$ & $0.2694(9)$ \\
\hline$C(216)$ & $0.5275(7)$ & $0.2199(6)$ & $0.2360(6)$ \\
\hline$C(221)$ & $0.5451(6)$ & $0.0403(4)$ & $0.2389(5)$ \\
\hline $\mathrm{C}(222)$ & $0.6216(7)$ & $0.0479(5)$ & $0.2964(6)$ \\
\hline$C(223)$ & $0.7004(7)$ & $0.0062(6)$ & $0.2924(7)$ \\
\hline$C(224)$ & $0.7066(7)$ & $-0.0412(5)$ & $0.2328(6)$ \\
\hline$C(225)$ & $0.6302(7)$ & $-0.0508(6)$ & $0.1758(6)$ \\
\hline $\mathrm{C}(226)$ & $0.5512(7)$ & $-0.0093(5)$ & $0.1799(6)$ \\
\hline$C(231)$ & $0.3802(6)$ & 0.0545 & $0.3322(5)$ \\
\hline $\mathrm{C}(232)$ & $0.4124(8)$ & $-0.0068(6)$ & $0.3650(7)$ \\
\hline $\mathrm{C}(233)$ & $0.3648(9)$ & $-0.0364(7)$ & $0.4312(8)$ \\
\hline $\mathrm{C}(234)$ & $0.2907(9)$ & $0.0006(7)$ & $0.4601(8)$ \\
\hline $\mathrm{C}(235)$ & $0.2587(7)$ & $0.0615(6)$ & $0.4285(6)$ \\
\hline $\mathrm{C}(236)$ & $0.3038(6)$ & $0.0889(5)$ & $0.3636(6)$ \\
\hline
\end{tabular}

accuracy of ${ }^{195} \mathrm{Pt}$ chemical shifts is $\pm 0.5 \mathrm{ppm}$ while for the ${ }^{31} \mathrm{P}-{ }^{195} \mathrm{Pt}$ coupling constants measured through $2 \mathrm{D}$ experiments the accuracy is $\pm 5 \mathrm{~Hz}$.

A ${ }^{1} \mathrm{H} 2 \mathrm{D}$ exchange experiment $(200.13 \mathrm{MHz})$ was performed at $294 \mathrm{~K}$ on a solution of compounds $3 \mathbf{a}$ and $3 \mathbf{b}$ in THF- $d_{8}$. The experiment was performed in the phase-sensitive mode using the pulse sequence described by Bodenhausen et al. ${ }^{25}$ A total of 48 FIDs of $1 \mathrm{~K}$ data points were recorded for each of the 256 increments in $t_{1}$ (spectral width $6000 \mathrm{~Hz}$, mixing time $0.5 \mathrm{~s}$, relaxation delay $2 \mathrm{~s}$ ).

X-ray Analysis. Intensity Measurements. Crystal data are reported in Table III. A crystal sample was mounted on a glass fiber in air. The intensity data were collected on an Enraf-Nonius $\mathrm{CAD} 4$ automated diffractometer. The setting angles of 25 random intense reflections $\left(16<2 \theta<25^{\circ}\right)$ were used to determine by least-squares fit accurate cell constants and orientation matrix. The intensities were collected by using a variable scan range with a $25 \%$ extension at each end of the scan range for background determination. A total decay of the sample of ca. $16 \%$ was observed during the collection by monitoring the intensities of three intense reflections at regular intervals. The intensities were corrected for Lorentz, polarization, and decay effects. An empirical absorption correction was also applied to the data, based on $\psi$-scans $\left(\psi 0-360^{\circ}\right.$ every $\left.10^{\circ}\right)$ of suitable reflections with $\chi$ values close to $90^{\circ}$.

Structure Solution and Refinements. All computations were performed on a PDP $11 / 34$ computer, using the EnrafNonius structure determination package (SDP), and the physical constants therein tabulated.

The structure solution was based on the deconvolution of a three-dimensional Patterson map, which gave the positions of the heavy atoms. Successive difference-Fourier maps revealed the location of all the remaining non-hydrogen atoms.

The refinements were carried out by full-matrix least-squares analysis. Anisotropic thermal factors were assigned to all atoms with the exception of the phenyl carbon atoms. The hydrogen atoms of the phenyl groups were placed in their ideal position (C-H $0.95 \AA, B 5.0 \AA^{2}$ ) at the end of each cycle of refinement but not refined.

The final difference-Fourier map was rather flat, not showing peaks exceeding ca. $0.9 \mathrm{e} \AA^{-3}$. No clear evidence of peaks attributable to the two hydrides was obtained. These atoms were, therefore, placed in idealized positions, bridging the $\operatorname{Re}(1)-\operatorname{Re}(2)$ and the $\mathrm{Pt}-\mathrm{Re}(1)$ edges, with a mean metal-hydrogen distance of ca. $1.83 \AA{ }^{16}$ They were included in the model but not refined.

Weights were assigned according to the formula $w=4 F_{\circ}^{2} / \sigma$ $\left(F_{0}^{2}\right)^{2}$, where $\sigma\left(F_{o}^{2}\right)=\left[\sigma(I)^{2}+(p I)^{2}\right]^{1 / 2} / L_{p}\left(I\right.$ and $L_{p}$ being the integrated intensity and the Lorentz-polarization correction, respectively); $p$ was optimized to the value 0.04 . The final values of the conventional agreement indices $R$ and $R_{\mathrm{w}}$ are given in Table III, and those of the final positional parameters in Table IV.

Acknowledgment. We thank the Progetto Finalizzato Chimica Fine II of the Italian Consiglio Nazionale delle Ricerche and Italian Ministero della Pubblica Istruzione for financial support and instrumental facilities.

Supplementary Material Available: Tables of anisotropic and isotropic thermal parameters, of the calculated coordinates of the hydrogen atoms, and of bond distances and angles within the phosphine ligands and the contour plot of the ${ }^{1} \mathrm{H} 2 \mathrm{D}$ exchange experiment for $\mathbf{3 a}$ and $\mathbf{3 b}$ ( 9 pages); a list of observed and calculated structure factor moduli ( 35 pages). Ordering information is given on any current masthead page.

(25) Bodenhausen, G.; Kogler, H.; Ernst, R. R. J. Magn. Reson. 1984 58,370 . 